\title{
Pengaruh Kompleksitas Tugas, Tekanan Anggaran Waktu Dan Pengalaman Auditor Terhadap Kualitas Audit
}

\author{
Ni Luh Dwi Ariestanti ${ }^{1}$ \\ Made Yenni Latrini ${ }^{2}$ \\ ${ }^{1,2}$ Fakultas Ekonomi dan Bisnis Universitas Udayana (Unud), Bali, Indonesia \\ e-mail: dwi.ariestanti87@gmail.com
}

\begin{abstract}
ABSTRAK
Dewasa ini persaingan antar perusahaan semakin meningkat diiringi dengan berbagai masalah yang dihadapi oleh perusahaan di Indonesia. Dalam menghadapi masalah itu para pengelola perusahaan membutuhkan jasa akuntan, khususnya jasa akuntan publik. Kualitas audit merupakan salah satu hal yang penting dalam menujunag eksistensi suatu perusahaan. Penelitian ini bertujuan untuk membuktikan secara empiris pengaruh kompleksitas tugas, tekanan anggaran waktu dan pengalaman auditor terhadap kualits audit. Penelitian ini adalah penelitian kuantitatif yang bersifat asosiatif. Data yang dipergunakan dalam penelitian ini adalah data primer yang diperoleh dengan menyebarkan kuesioner kepada masing-masing auditor pada 9 Kantor Akuntan Publik (KAP) yang tersebar di Provinsi Bali. Teknik analisis yang digunakan dalam penelitian ini adalah analisis linear berganda. Hasil uji menujukan kompleksitas tugas berpengaruh negatif dan signifikan pada kualitas audit. Tekanan anggaran waktu berpengaruh positif dan signifikan pada kualitas audit. Pengalaman auditor berpengaruh positif dan signifikan pada kualitas audit.
\end{abstract}

Kata Kunci: Kompleksitas tugas, tekanan anggaran waktu, pengalaman auditor, kualitas audit

\begin{abstract}
At this time competition between companies is increasing accompanied by various problems faced by companies in Indonesia. In dealing with this problem, the company managers need accountant services, especially public accounting services. Audit quality is one of the important things in approaching the existence of a company. This study aims to prove empirically the effect of task complexity, time budget pressure and auditor experience on audit quality. This research is associative quantitative research. The data used in this study is primary data obtained by distributing questionnaires to each auditor at 9 Public Accounting Firms (KAP) in Province of Bali. The analysis technique used in this study is multiple linear analysis. The test results aimed at task complexity have a negative and significant effect on audit quality. Time budget pressure has a positive and significant effect on audit quality. The auditor's experience has a positive and significant effect on audit quality.

Keywords: Task complexity, time budget pressure, auditor experience, audit quality
\end{abstract}

\section{PENDAHULUAN}

Dewasa ini persaingan antar perusahaan semakin meningkat diiringi dengan berbagai masalah yang dihadapi oleh perusahaan di Indonesia. Dalam menghadapi 
Ni Luh Dwi Ariestanti dan Made Yenni Latrini. Pengaruh ...

masalah itu para pengelola perusahaan membutuhkan jasa akuntan, khususnya jasa akuntan publik. Akuntan dalam hal ini adalah auditor yaitu suatu profesi yang salah satu tugasnya melaksanakan audit terhadap laporan keuangan sebuah perusahaan dan memberikan opini (Hidayat, 2011). Berkembangnya perusahaan di Indonesia dewasa ini, kebutuhan akan jasa akuntan publik pun semakin meningkat. Untuk memberikan keyakinan bahwa laporan keuangan yang disajikan oleh manajemen bebas dari salah saji material, maka perusahaan membutuhkan jasa akuntan publik agar laporan keuangan teruji secara independen serta menunjang pembuatan keputusan bisnis.

Akuntan publik adalah akuntan yang telah memperoleh izin dari menteri keuangan untuk memberikan jasa akuntan publik di Indonesia. Ketentuan mengenai akuntan publik di Indonesia diatur dalam Undang-Undang Republik Indonesia Nomor 5 tahun 2011 tentang Akuntan Publik dan Peraturan Menteri Keuangan Nomor 17/PMK.01/2008 tentang Jasa Akuntan Publik. Setiap akuntan publik wajib menjadi anggota Institut Akuntan Publik Indonesia (IAPI), asosiasi profesi yang diakui oleh Pemerintah. Pengertian Kantor Akuntan Publik (KAP) adalah suatu bentuk organisasi akuntan publik yang memperoleh ijin sesuai dengan peraturan perundang-undangan yang berusaha di bidang pemberian jasa profesional dalam praktik akuntan publik. Jasa yang diberikan berupa jasa audit operasional, audit kepatuhan, dan audit laporan keuangan (Arens dan Loebbecke, 2003). Seorang auditor menemukan dan melaporkan tentang adanya suatu pelanggaran dalam sistem akuntansi kliennya. 
Akuntan publik bertugas memberikan opini tentang kewajaran laporan keuangan sebagai dasar dalam pembuatan keputusan bahwa laporan keuangan yang disajikan oleh manajemen dapat dipercaya. Kepercayaan yang telah diberikan kepada akuntan publik, mengharuskan akuntan publik untuk memperhatikan kualitas audit yang dilakukannya. (Kane \& Velury, 2005) mendefinisikan kualitas audit sebagai kapasitas auditor eksternal untuk mendeteksi terjadinya kesalahan material dan bentuk penyimpangan lainnya. Temuan pelanggaran mengukur kualitas audit berkaitan dengan pengetahuan dan keahlian auditor. Sedangkan pelaporan pelanggaran tergantung kepada dorongan auditor untuk mengungkapkan pelanggaran tersebut (Fonda., 2014).

Berbagai kasus audit yang telah terjadi, salah satunya yang paling terkenal dan cukup memberi dampak signifikan pada kepercayaan publik terhadap profesi akuntan publik dalam kualitas auditnya yaitu kasus Enron yang melibatkan Kantor Akuntan Publik Arthur Anderson. Publik mulai mempertanyakan tentang kualitas audit yang diberikan akuntan publik dalam mengaudit laporan keuangan perusahaan kliennya. Beberapa kasus audit lainnya juga pernah terjadi di Bali, dikutip dari (Okezone.com, 2011) menjukkan bahwa penyimpangan anggaran dalam bentuk tindak pidana korupsi yang terjadi di wilayah Bali tercatat 21 kasus dengan nilai kerugian negara mencapai sekira Rp17,02 miliar lebih.

Dari 53 kasus tindak pidana korupsi, 21 kasus di antaranya terjadi di Bali dengan nilai Rp 17,02 miliar lebih. Data tersebut terungkap berdasar hasil audit 
Ni Luh Dwi Ariestanti dan Made Yenni Latrini. Pengaruh ...

Badan Pengawasan Keuangan dan Pembangunan (BPKP) Perwakilan Provinsi Bali yang membawahi wilayah Provinsi Bali dan NTB.

Hasil penelitian (Josoprijonggo, 2005) agar laporan audit yang dihasilkan auditor berkualitas, maka auditor harus menjalankan pekerjaannya secara professional. Termasuk saat menghadapi persoalan audit yang kompleks. Untuk itu maka keberadaan Kantor Akuntan Publik (KAP) sangat penting untuk mendapatkan hasil audit yang berkualitas. Auditor harus bisa memenuhi tuntutan yang diinginkan oleh klien, walaupun seberapa tinggi tingkat kompleksitas yang diberikan agar klien merasa puas dengan pekerjaannya dan tetap menggunakan jasa auditor yang sama diwaktu yang akan datang.

Kompleksitas tugas didasarkan pada persepsi individu tentang kesulitan suatu tugas audit, sulit bagi seseorang namun mudah bagi orang lain (Restuningdiah, N. dan Indriantoro, 2000) dalam (Andin prasita dan Hadi Priyo, 2007). Kompleksitas tugas juga bersifat penting karena kecenderungan bahwa tugas melakukan audit adalah tugas yang banyak menghadapi persoalan kompleks. (Bonner, 1994) dalam (Jamilah, Siti, Fanani, Zaenal dan Chandrarin, 2007) mengemukakan ada tiga alasan yang cukup mendasar mengapa pengujian terhadap kompleksitas tugas untuk sebuah situasi audit perlu dilakukan.

Pertama, kompleksitas tugas ini diduga berpengaruh signifikan terhadap kinerja seorang auditor. Kedua, sarana dan teknik pembuatan keputusan dan latihan tertentu diduga telah dikondisikan sedemikian rupa ketika para peneliti memahami keganjilan pada kompleksitas tugas. Ketiga, pemahaman terhadap 
kompleksitas dari sebuah audit dapat membantu tim manajemen audit perusahaan menemukan solusi terbaik bagi staf audit dan tugas audit. Lebih lanjut (Restuningdiah, N. dan Indriantoro, 2000) dalam (Andin prasita dan Hadi Priyo, 2007) menyatakan bahwa peningkatan kompleksitas tugas atau sistem, akan menurunkan tingkat keberhasilan hasil audit itu. Terkait dengan tingginya kompleksitas tugas akan menyebabkan penurunan kualitas audit.

Faktor lain yang mempengaruhi kualitas audit adalah tekanan anggaran waktu yang diberikan oleh klien. Tekanan anggaran waktu menyebabkan stress individual yang muncul akibat tidak seimbangnya tugas dan waktu yang tersedia serta mempengaruhi etika professional melalui sikap, nilai, perhatian, dan perilaku auditor (Sososutikno, 2003). Tekanan anggaran waktu salah satunya disebabkan oleh tingkat persaingan yang semakin tinggi antar Kantor Akuntan Publik (KAP) dalam (Simanjuntak, 2008).

Tuntutan laporan yang berkualitas dengan waktu yang terbatas merupakan tekanan tersendiri bagi auditor. Dalam studinya, (Azad, 1994) menemukan bahwa kondisi yang tertekan (secara waktu), auditor cenderung berperilaku disfungsional, misal melakukan premature sign off, terlalu percaya pada penjelasan dan presentasi klien, serta gagal mengivestigasi isu-isu relevan, yang pada gilirannya dapat menghasilkan laporan audit berkualitas rendah. Riset (Coram, Ng, \& Woodliff, 2003) menunjukkan terdapat penurunan kualitas audit pada auditor yang mengalami tekanan dikarenakan anggaran waktu yang sangat ketat. 
Ni Luh Dwi Ariestanti dan Made Yenni Latrini. Pengaruh ...

Faktor lain yang juga penting dalam mempengaruhi kualitas audit yaitu pengalaman. Menurut (Loehoer, 2002) pengalaman merupakan akumulasi gabungan dari semua yang diperoleh melalui berhadapan dan berinteraksi secara berulang-ulang dengan sesama, benda, alam, keadaan, gagasan, dan penginderaan. Dari hasil penelitian yang dilakukan oleh (Hardiningsih, 2002) disebutkan bahwa auditor yang tidak berpengalaman akan melakukan kesalahan lebih besar dibandingkan dengan auditor yang berpengalaman. Jangka waktu bekerja seseorang sebagai auditor menjadi bagian penting yang mempengaruhi kualitas audit. Dengan bertambahnya waktu bekerja auditor maka akan diperoleh pengalaman baru.

Teori keperilakuan adalah suatu ilmu yang mempelajari perilaku manusia. Teori keperilakuan menjelaskan interaksi antara kompleksitas tugas, tekanan anggaran waktu, dan pengalaman auditor terhadap kualitas audit. Pemahaman terhadap kompleksitas tugas dan tekanan anggaran waktu serta pengalaman dari auditor berhubungan dengan perilaku individu untuk menggunakan srategi dalam penyelesaian tugas rutin, yaitu seberapa jauh kompleksitas, tekanan anggaran waktu dan pengalaman auditor sebagai alat bantu terintegrasi pada setiap pekerjaan baik karena pilihan individual maupun mandate dari organisasi (Jurnali, 2001).

Teori keperilakuan menjelaskan hubungan antara variabel kompleksitas dengan kualitas audit. Badan audit research ternama telah mendemonstrasikan bahwa sejumlah faktor level individu terbukti berpengaruh terhadap perilaku 
seorang auditor (Solomon, I. Shields, 1995) dan bahwa pengaruh dari keberadaan faktor-faktor ini berubah-ubah seiring dengan meningkatnya kompleksitas tugas yang dihadapi (Tan \& Kao, 1999) ; (R. Libby, 1995) dalam (Jamilah , Siti, Fanani , Zaenal dan Chandrarin, 2007). Tingginya tingkat kompleksitas tugas mempengaruhi perilaku auditor yang cenderung disfungsional sehingga menyebabkan penurunan kualitas audit.

Kompleksitas tugas didasarkan pada persepsi individu tentang kesulitan suatu tugas audit. (Restuningdiah, N. dan Indriantoro, 2000) menyatakan bahwa peningkatan kompleksitas dalam suatu tugas atau sistem, akan menurunkan tingkat keberhasilan tugas itu. Terkait dengan kegiatan pengauditan, tingginya kompleksitas tugas dapat menyebabkan akuntan berperilaku disfungsional sehingga menyebabkan penurunan kualitas audit. Demikian juga pada penelitian (Andin prasita dan Hadi Priyo, 2007) menunjukkan hasil bahwa, kompleksitas tugas mempunyai pengaruh negatif terhadap kualitas audit. Namun dalam penelitian yang dilakukan (Setyawati, 2010) menunjukkan hasil yang berbeda, bahwa variabel kompleksitas tugas berpengaruh positif terhadap kualitas audit. Penelitiannya menunjukkan, kompleksitas tugas yang positif berarti dengan kompleksitas tugas yang tinggi diharapkan tingkat kerumitan tugas maupun variasi tugas akan mendorong meningkatnya kemampuan auditor sehingga menghasilkan kualitas audit yang maksimal. Berdasarkan hasil penelitian tersebut hipotesis pertama yang diajukan adalah sebagai berikut.

$\mathrm{H}_{1}$ : Kompleksitas tugas berpengaruh negatif terhadap kualitas audit. 
Ni Luh Dwi Ariestanti dan Made Yenni Latrini. Pengaruh ...

Teori keperilakuan menjelaskan hubungan antara variable tekanan anggaran waktu dengan kualitas audit. (DeZoort \& Lord, 1997) dalam (Nataline, 2007) yang menyebutkan bahwa saat menghadapi tekanan anggaran waktu, auditor akan memberikan respon dengan dua cara yaitu, fungsional dan disfungsional. Jadi dengan adanya tekanan anggaran waktu dapat mempengaruhi perilaku auditor yang kemudian menyebabkan penurunan kualitas audit. Menurut hasil penelitian (Andin prasita dan Hadi Priyo, 2007) menunjukkan hasil bahwa tekanan anggaran waktu mempunyai pengaruh negatif terhadap kualitas audit. Penelitian (Simanjuntak, 2008) yang menunjukkan hasil tekanan anggaran waktu membuat auditor cenderung untuk melakukan tindakan yang menyebabkan penurunan kualitas audit.

Tetapi, penelitian ini bertolak belakang dengan penelitian (Sososutikno, 2003) dan (Shintya, Agneus., Muhammad Nuryatno., 2016), yang menunjukan hasil bahwa tekanan anggaran waktu berpengaruh positif terhadap kualitas audit, dimana tekanan anggaran waktu yang semakin ketat justru mendorong auditor untuk lebih semangat dalam menyelesaikan tugas auditnya sehingga dapat meningkatkan kualitas audit. Berdasarkan hasil penelitian tersebut hipotesis kedua yang diajukan adalah sebagai berikut.

$\mathrm{H}_{2}$ : Tekanan anggaran waktu berpengaruh negatif terhadap kualitas audit.

Teori keperilakuan menjelaskan hubungan antar variabel pengalaman auditor dengan kualitas audit. Auditor yang tidak berpengalaman akan melakukan atribusi kesalahan lebih besar dibandingkan dengan auditor yang berpengalaman. 
Jadi pengalaman mempengaruhi perilaku auditor yang kemudian akan mempengaruhi kualitas audit. Pengalaman auditor merupakan tingkat penguasaan dan pemahaman auditor dari lamanya auditor tersebut bekerja. Menurut (Futri, 2014) pengalaman juga terkait dengan masa kerja akuntan publik, semakin lama rentan waktu masa kerja akuntan publik juga berpengaruh terhadap setiap keputusan yang diambil. Hasil penelitian yang dilakukan oleh (Choo \& Trotman, 1991), menunjukkan bahwa auditor yang berpengalaman lebih banyak menemukan butir-butir yang tidak umum dibanding auditor yang kurang berpengalaman.

Tetapi untuk menemukan butir-butir yang umum, tidak ada bedanya antara auditor berpengalaman dan auditor yang kurang berpengalaman. Menurut hasil penelitian (Nataline, 2007) menunjukkan hasil bahwa pengalaman auditor mempunyai pengaruh positif terhadap kualitas audit. Demikian juga pada penelitian (Ananing, 2006) yang menunjukkan hasil bahwa pengalaman dan lamanya bekerja auditor berpengaruh positif terhadap peningkatan keahlian auditor dalam bidang auditing. Berbeda dengan hasil penelitian (Jauhari, 2013) menemukan bahwa pengalaman kerja berpengaruh negatif terhadap kualitas audit. Hasil ini menujukkan masih terjadi ketidakkonsistenan hasil penelitian. Berdasarkan hasil penelitian tersebut hipotesis ketiga yang dapat diajukan adalah sebagai berikut.

$\mathrm{H}_{3}$ : Pengalaman auditor berpengaruh positif terhadap kualitas audit. 


\section{METODE PENELITIAN}

Pendekatan yang digunakan dalam penelitian ini adalah pendekatan kuantitatif berbentuk asosiatif, yang bertujuan untuk mengetahui hubungan antara dua variabel atau lebih. Penelitian ini menggunakan data primer dengan menyebarkan kuesioner kepada auditor yang bekerja pada Kantor Akuntan Publik (KAP) di Provinsi Bali. Penelitian ini dilakukan pada Kantor Akuntan Publik (KAP) yang berada di Bali yang terdaftar dalam Direktori yang diterbitkan oleh Institut Akuntan Publik Indonesia tahun 2016. Alasan dipilihnya lokasi ini adalah untuk memudahkan dalam pengumpulan data karena kantor akuntan publik yang terdaftar dalam Direktori akan mudah diketahui nama dan alamatnya dan telah memperoleh izin dari Menteri Keuangan RI sebagai wadah dari akuntan publik dalam melaksanakan pekerjaannya.

Variabel terikat dalam penelitian ini adalah kualitas audit (Y). Kualitas audit merupakan gabungan probabilitas seorang auditor untuk menemukan dan melaporkan penyelewengan yang terjadi dalam sistem akuntansi klien (Simanjuntak, 2008). Kualitas Audit merupakan variable dependen yang diukur dengan indicator dari (Nataline, 2007) yaitu: 1) Independensi, 2) Ketaatan memenuhi standar auditing dalam penugasan audit, 3) Kecukupan bukti pemeriksaan, 4) Kehati-hatian dalam pengambilan keputusan. Persepsi responden terhadap indikator tersebut diukur dengan 5 point skala likert, 1) Sangat tidak setuju, 2) Tidak setuju, 3) Netral, 4) Setuju, 5) Sangat Setuju. 
Variabel bebas dalam penelitian ini adalah kompleksitas tugas $\left(\mathrm{X}_{1}\right)$, tekanan penganggaran waktu $\left(\mathrm{X}_{2}\right)$ dan pengalaman auditor $\left(\mathrm{X}_{3}\right)$. Kompleksitas tugas merupakan kesulitan suatu tugas yang dihadapi para auditor dengan tingkat kesulitan yang berbeda-beda yang timbul karena beragamnya outcome yang diharapkan oleh klien (Cecilia Engko dan Gudono, 2007). Kompleksitas tugas merupakan variabel independen yang diukur dengan menggunakan indikator dari (Jamilah , Siti, Fanani, Zaenal dan Chandrarin, 2007) yaitu; 1) kejelasan tugas. 2) banyaknya informasi yang diterima auditor. Persepsi responden terhadap indikator tersebut diukur dengan 5 point skala likert, 1) Sangat tidak setuju, 2) Tidak setuju, 3) Netral, 4) Setuju, 5) Sangat Setuju.

Tekanan anggaran waktu adalah suatu keadaan yang menunjukkan auditor dituntut untuk melakukan efisiensi terhadap anggaran waktu yang telah disusun atau terdapat pembatasan waktu dalam anggaran yang sangat ketat dan kaku (Sososutikno, 2003). Tekanan Anggaran Waktu merupakan variable independen yang diukur menggunakan indikator dari (Nataline, 2007) yaitu: 1) ketepatan dan tambahan waktu, 2) pemenuhan target dengan waktu yang ditentukan, 3) beban yang ditanggung dengan keterbatasan waktu. Persepsi responden terhadap indikator tersebut diukur dengan 5 point skala likert, 1) Sangat tidak setuju, 2) Tidak setuju, 3) Netral, 4) Setuju, 5) Sangat Setuju.

Menurut (Loehoer, 2002) pengalaman auditor merupakan akumulasi gabungan dari semua yang diperoleh melalui interaksi secara berulang. Pengalaman auditor merupakan variable independen yang diukur dengan indikator 
Ni Luh Dwi Ariestanti dan Made Yenni Latrini. Pengaruh ...

yaitu: 1) Banyaknya klien yang diaudit, 2) Lamanya masa kerja, 3) Pengalaman mengikuti pelatihan. 4) Pengalaman share dengan auditor senior. Persepsi responden terhadap indikator tersebut diukur dengan 5 point skala likert, 1) Sangat tidak setuju, 2) Tidak setuju, 3) Netral, 4) Setuju, 5) Sangat Setuju.

Data kuantitatif merupakan data penelitian yang berupa angka-angka dan analisis menggunakan statistic (Sugiyono, 2017). Data kuantitatif diperoleh dari kuisioner yang mengacu pada pengukuran variabel yang digunakan. Data primer dalam penelitian ini adalah dari jawaban atau skor responden terhadap kuesioner yang diajukan.

Populasi dalam penelitian ini adalah seluruh auditor yang bekerja pada Kantor Akuntan Publik (KAP) di Provinsi Bali. Metode penentuan sampel dalam penelitian ini adalah purposive sampling, yaitu teknik penentuan sampel dengan pertimbangan tertentu diantaranya, 1) auditor pada Kantor Akuntan Publik di Bali yang sudah bekerja secara tim, 2) masih bersatus aktif yang tidak dibatasi jabatannya sebagai auditor baik partner, manajer, auditor senior atau auditor junior. Responden dalam penelitian ini adalah sebanyak 63 auditor yaitu setiap KAP diberikan 7 kuesioner.

Teknik analisis yang digunakan dalam penelitian ini adalah analisis regresi berganda, teknik analisis regresi linear berganda yang diuji dengan tingkat signifikansi 0,05. Analisis regresi linear berganda digunakan untuk mengetahui atau memperoleh gambaran mengenai pengaruh variabel bebas $\left(\mathrm{X}_{1}, \mathrm{X}_{2}, \mathrm{X}_{3}\right.$, $)$ pada variabel terikat $(\mathrm{Y})$. Analisis ini dilakukan dengan menggunakan bantuan program 
komputer Statistical Package for Social Science (SPSS). Model regresi linear berganda di tunjukkan oleh persamaan sebagai berikut.

$$
\hat{Y}=\alpha+\beta_{1} X_{1}+\beta_{2} X_{2}+\beta_{3} X_{3}+\text { e. }
$$

Keterangan:

$\hat{\mathrm{Y}} \quad=$ kualitas audit

$\alpha \quad=$ konstanta

$\beta \quad=$ koefisien regresi parsial

$\mathrm{X}_{1} \quad=$ Komplesitas tugas

$\mathrm{X}_{2} \quad=$ tekanan anggaran

$\mathrm{X}_{3} \quad=$ pengalaman auditor

e $\quad$ standar error

\section{HASIL DAN PEMBAHASAN}

Penelitian ini dilakukan untuk mengetahui pengaruh kompleksitas tugas, tekanan anggaran waktu dan pengalaman auditor terhadap kualitas audit pada Kantor Akuntan Publik di Bali. Data dikumpulkan dengan menyebar kuesioner ke tujuh kantor Akuntan Publik di Bali. Ringkasan pengiriman dan pengembalian kuesioner disajikan pada Tabel 1.

Tabel 1.

Rincian Pengiriman dan Pengembalian Kuesioner

\begin{tabular}{lcc}
\hline \multicolumn{1}{c}{ Kuesioner } & Jumlah & Persentase \\
\hline Kuesioner yang disebar & 63 & $100 \%$ \\
Kuesioner yang tidak kembali & 7 & $11,1 \%$ \\
Kuesioner yang kembali & 56 & $88,9 \%$ \\
Kuesioner yang digunakan & 56 & $88,9 \%$ \\
Tingkat pengembalian kuisioner & $56 / 63 \times 100 \%$ & $88,9 \%$ \\
\hline Sumber: Data diolah, 2016 & &
\end{tabular}

Tabel 1 menunjukan bahwa kuesioner yang disebar ke responden sebanyak 63 kuesioner, yang kembali sebanyak 56 kuesioner, sedangkan yang tidak 
Ni Luh Dwi Ariestanti dan Made Yenni Latrini. Pengaruh ...

dikembalikan sebanyak 7 kuesioner. Semua kuesioner yang kembali lengkap pengisiannya dan memenuhi ketentuan, kemudian dianalisis.

Karakteristik responden penelitian ini merupakan profil dari 66 responden yang berpartisipasi dalam pengisian kuesioner. Karakteristik responden penelitian meliputi jenis kelamin, jenjang pendidikan dan lama bekerja, Karakteristik responden dapat dilihat pada Tabel 2, Tabel 3, dan Tabel 4.

Tabel 2.

Karakteristik Responden Berdasarkan Jenis Kelamin

\begin{tabular}{lcc}
\hline Jenis Kelamin & Jumlah (Orang) & Persentase $(\%)$ \\
\hline Laki-Laki & 44 & 78,6 \\
Perempuan & 12 & 21,4 \\
Total & 56 & 100 \\
\hline
\end{tabular}

Sumber: Data diolah, 2018

Tabel 2 menunjukan proporsi auditor laki-laki dan perempuan berdasarkan jenis kelamin dapat diketahui jumlah auditor laki-laki sebanyak 44 orang responden 78,6 persen dan auditor perempuan sebanyak 12 orang responden 21,4 persen. Ini menandakan responden pada Kantor KAP di dominasi oleh auditor laki-laki dikarenakan auditor laki-laki dianggap lebih teliti dan berani mengambil resiko dalam bekerja tanpa memperdulikan tekanan dari pihak-pihak tertentu.

Tabel 3.

Karakteristik Responden Berdasarkan Pendidikan Terakhir

\begin{tabular}{|c|c|c|}
\hline Pendidikan Terakhir & Jumlah (Orang) & Persentase $(\%)$ \\
\hline Diploma 3 & 8 & 14,3 \\
\hline S1 & 38 & 67,9 \\
\hline S2 & 10 & 17,8 \\
\hline Total & 56 & 100 \\
\hline
\end{tabular}

Sumber: Data diolah, 2018

Berdasarkan Undang-Undang Republik Indonesia Nomor 20 Tahun 2003 Tentang Sistem Pendidikan, pendidikan adalah usaha sadar dan terencana untuk mewujudkan suasana belajar dan proses pembelajaran agar peserta didik secara 
aktif mengembangkan potensi dirinya untuk memiliki kekuatan dan pemahaman tentang spiritual/keagamaan, pengendalian diri, kepribadian, kecerdasan, akhlak mulia, serta keterampilan yang diperlukan dirinya, masyarakat, bangsa, dan negara. Pada Tabel 3 responden yang memiliki tingkat pendidikan Diploma sebanyak 8 orang 14,3 persen, S1 sebanyak 38 orang atau 67,9 persen dan S2 sebanyak 10 orang atau sebanyak 17,8 persen. Ini menandakan rata-rata tingkat pendidikan auditor adalah S1, yang memiliki arti semakin baik tingkat pendidikan seorang auditor mampu menunjukkan tingkat kinerja yang tinggi dengan kualitas hasil audit yang lebih baik.

Tabel 4.

Karakteristik Responden Berdasarkan Lama Bekerja

\begin{tabular}{|c|c|c|}
\hline Lama Bergabung Sebagai Tim Audit & Jumlah (Orang) & Persentase $(\%)$ \\
\hline Kurang dari 5 tahun & 22 & 39,3 \\
\hline$>5 \mathrm{~s} / \mathrm{d} 10$ tahun & 34 & 60,7 \\
\hline Total & 56 & 100 \\
\hline
\end{tabular}

Sumber: Data diolah, 2018

Tabel 4 berfungsi untuk mengetahui lama seorang auditor bergabung dalam suatu tim audit pada Kantor KAP. Tabel 4 menunjukkan responden yang tergabung dalam tim audit kurang dari lima tahun sebanyak 22 orang atau 39,3 persen. Responden yang tergabung dalam tim audit lebih dari lima tahun sebanyak 34 orang 60,7 persen. Dapat dijelaskan seluruh responden sudah pernah tergabung dalam tim audit pada Kantor KAP sehingga responden yang digunakan dalam penelitian ini layak digunakan dan menunjukkan data yang valid, karena dengan bergabungnnya dalam tim audit tentunya akan menambah atau meningkatkan standar kualitas audit yang dilakukan. 
Ni Luh Dwi Ariestanti dan Made Yenni Latrini. Pengaruh ...

Pengujian validitas tiap butir digunakan analisis item yaitu mengkorelasikan skor tiap item dengan skor total item. Nilai korelasi antar skor item dengan total item kemudian dibandingkan dengan koefisien korelasi " $\mathrm{r}$ ". Jika korelasi item terhadap skor total lebih besar dari koefisien korelasi " $r$ " $(0,30)$ maka instrumen dikatakan valid. Suatu kuesioner dikatakan valid jika pernyataan pada kuesioner mampu untuk mengungkapkan sesuatu yang diukur oleh kuesioner tersebut. Hasil uji validitas instrumen penelitian akan disajikan pada Tabel 5.

Tabel 5.

Hasil Uji Validitas

\begin{tabular}{|c|c|c|c|}
\hline Variabel & Pernyataan & Pearson Correlation & Keterangan \\
\hline Kompleksitas & $\mathrm{X}_{1.1}$ & 0,538 & Valid \\
\hline$\left(\mathrm{X}_{1}\right)^{\prime}$ & $\mathrm{X}_{1.2}$ & 0,453 & Valid \\
\hline & $\mathrm{X}_{1.3}$ & 0,568 & Valid \\
\hline Tekanan Anggaran & $\mathrm{X}_{2.1}$ & 0,534 & Valid \\
\hline Waktu $\left(\mathrm{X}_{2}\right)$ & $\mathrm{X}_{2.2}$ & 0,491 & Valid \\
\hline & $\mathrm{X}_{2.3}$ & 0,436 & Valid \\
\hline Pengalaman auditor & $\mathrm{X}_{3.1}$ & 0,718 & Valid \\
\hline$\left(\mathrm{X}_{3}\right)$ & $\mathrm{X}_{3.2}$ & 0,304 & Valid \\
\hline & $\mathrm{X}_{3.3}$ & 0,715 & Valid \\
\hline & $\mathrm{X}_{3.4}$ & 0,476 & Valid \\
\hline Kualitas Audit (Y) & $\mathrm{Y}_{1}$ & 0,312 & Valid \\
\hline & $\mathrm{Y}_{2}$ & 0,659 & Valid \\
\hline & $\mathrm{Y}_{3}$ & 0,640 & Valid \\
\hline & $\mathrm{Y}_{4}$ & 0,758 & Valid \\
\hline
\end{tabular}

Sumber: Data diolah, 2018

Tabel 5 menunjukkan bahwa seluruh indikator pernyataan dalam variabel kompleksitas tugas, tekanan anggaran waktu, pengalaman auditor dan kualitas audit memiliki nilai pearson correlation yang lebih besar dari 0,30. Dengan demikian dapat disimpulkan bahwa seluruh indikator telah memenuhi syarat uji validitas.

Reliabilitas menunjukkan sejauh mana suatu alat pengukur dapat dipercaya atau dapat diandalkan. Apabila suatu alat pengukur dipakai dua kali untuk 
mengukur gejala yang sama dan hasil pengukuran yang diperoleh relatif konsisten, maka alat pengukur tersebut reliabel. Pengujian reliabilitas dalam penelitian ini menggunakan metode Cronbach's Alpha. Instrumen dikatakan reliabel untuk mengukur variabel bila berada di atas angka 0,60 . Hasil pengujian reliabilitas instrumen dapat dilihat pada Tabel 6.

Tabel 6.

\section{Hasil Uji Reliabilitas}

\begin{tabular}{lcc}
\hline \multicolumn{1}{c}{ Variabel } & Cronbach's Alpha & Keterangan \\
\hline Kompleksitas tugas $\left(\mathrm{X}_{1}\right)$ & 0,692 & Reliabel \\
Tekanan anggaran waktu $\left(\mathrm{X}_{2}\right)$ & 0,632 & Reliabel \\
Pengalaman auditor $\left(\mathrm{X}_{3}\right)$ & 0,674 & Reliabel \\
Kualitas audit $(\mathrm{Y})$ & 0,706 & Reliabel \\
\hline
\end{tabular}

Sumber: Data diolah, 2018

Berdasarkan Tabel 6 menjelaskan bahwa seluruh instrumen penelitian yang digunakan yaitu kompleksitas tugas, tekanan anggaran waktu, pengalaman auditor dan kualitas audit memiliki koefisien Cronbach's Alpha lebih besar dari 0,60 sehingga instrumen yang digunakan dalam penelitian ini dinyatakan reliabel.

Sebelum dianalisis dengan teknik regresi, maka model persamaan regresi harus melalui uji asumsi klasik. Model regresi yang baik adalah model regresi yang di dalamnya tidak terdapat masalah data yang distribusinya normal, masalah multikolinearitas, dan masalah heteroskedastisitas. Adapun pengujian asumsi klasik yang dilakukan yaitu: uji normalitas, uji multikolinearitas, dan uji heteroskedastisitas

Uji normalitas ini dilakukan untuk menguji apakah dalam sebuah model regresi (variabel dependen dan variabel independen) memiliki distribusi normal atau tidak. Pengujian normalitas nilai residual dalam penelitian ini dilakukan 
Ni Luh Dwi Ariestanti dan Made Yenni Latrini. Pengaruh ...

dengan menggunakan metode Kolmogorov-Smirnov. Nilai signifikansi yang diperoleh apabila Asymp. Sig. (2-tailed)-nya lebih besar dari 0,05, maka data tersebut dikatakan berdistribusi normal (Ghozali, 2015). Hasil uji normalitas dapat disajikan dalam Tabel 7 sebagai berikut.

Tabel 7.

Hasil Uji Kolmogorov-Smirnov

\begin{tabular}{lr}
\hline & Unstandardized Residual \\
\hline $\mathrm{N}$ & 56 \\
Kolmogorov-Smirnov Z & 0,118 \\
Asymp. Sig. (2-tailed) & 0,251 \\
\hline Sumber: Data diolah, 2018 &
\end{tabular}

Tabel 7 menunjukkan bahwa nilai Kolmogorov-Smirnov Z sebesar 0,118 dengan nilai Asymp. Sig. (2-tailed) sebesar 0,251. Berdasarkan hasil tersebut menujukkan model regresi yang digunakan dalam penelitian ini memiliki distribusi normal, karena asymp.sig. yang dimiliki lebih besar dari alpha 0,05.

Uji multikolinearitas bertujuan untuk menguji apakah di dalam model regresi ditemukan adanya korelasi antar variabel bebas. Model regresi yang baik seharusnya tidak terjadi korelasi diantara variabel bebas. Suatu model regresi dapat dikatakan baik jika tidak terjadi multikolinearitas di dalamnya. Adanya multikolinearitas dapat dilihat dari nilai tolerance atau variance inflation factor (VIF). Jika nilai tolerance lebih dari $10 \%$ atau VIF Kurang dari 10, maka dikatakan tidak ada multikolinearitas. Hasil uji multikolinearitas disajikan pada Tabel 8. 
ISSN: 2302-8556

E-Jurnal Akuntansi Universitas Udayana

Vol.27.2.Mei (2019): 1231-1262

Tabel 8.

Hasil Uji Multikolinearitas

\begin{tabular}{lcc}
\hline \multicolumn{1}{c}{ Variabel } & Tolerance & VIF \\
\hline Kompleksitas tugas $\left(\mathrm{X}_{1}\right)$ & 0,857 & 1,167 \\
Tekanan anggaran waktu $\left(\mathrm{X}_{2}\right)$ & 0,899 & 1,113 \\
Pengalaman auditor $\left(\mathrm{X}_{3}\right)$ & 0,924 & 1,083 \\
\hline
\end{tabular}

Sumber: Data diolah, 2018

Tabel 8 dapat dilihat bahwa nilai tolerence masing-masing variabel lebih besar dari 10 persen dan nilai VIF lebih kecil dari 10, sehingga dapat disimpulkan bahwa dalam model regresi tidak terjadi multikolinearitas dan dapat digunakan dalam penelitian.

Uji heteroskedastisitas bertujuan untuk menguji apakah model regresi terjadi ketidaksamaan varians dari residual pengamatan ke pengamatan yang lain. Uji ini dapat dianalisis melalui uji gletser dengan melihat tingkat signifikansi, jika tingkat signifikansi berada di atas 0,05 maka model regresi ini bebas dari masalah heterokedastisitas. Hasil uji heteroskedastisitas disajikan pada Tabel 9.

Tabel 9.

Hasil Uji Heteroskedastisitas

\begin{tabular}{lcl}
\hline \multicolumn{1}{c}{ Variabel } & Sig. & Keterangan \\
\hline Kompleksitas tugas $\left(\mathrm{X}_{1}\right)$ & 0,203 & Bebas heteroskedastisitas. \\
Tekanan anggaran waktu $\left(\mathrm{X}_{2}\right)$ & 0,240 & Bebas heteroskedastisitas. \\
Pengalaman auditor $\left(\mathrm{X}_{3}\right)$ & 0,231 & Bebas heteroskedastisitas. \\
\hline
\end{tabular}

Sumber: Data diolah, 2018

Tabel 9 menunjukkan bahwa nilai sig. masing-masing variabel kompleksitas tugas, tekanan anggaran waktu dan pengalaman auditor sebesar 0,203; 0,240; dan 0,231 lebih besar dari 0,05 yang berarti variabel tersebut bebas heteroskedastisitas. 
Ni Luh Dwi Ariestanti dan Made Yenni Latrini. Pengaruh ...

Analisis regresi linear berganda diolah dengan bantuan software dengan hasil yang dapat dilihat pada Tabel 10 berikut.

Tabel 10.

Rangkuman Hasil Analisis Regresi Linear Berganda

\begin{tabular}{|c|c|c|c|c|c|}
\hline \multirow{2}{*}{ Variabel } & \multicolumn{2}{|c|}{$\begin{array}{l}\text { Unstandardized } \\
\text { Coefficients }\end{array}$} & \multirow{2}{*}{$\begin{array}{c}\text { Standardized } \\
\text { Coefficients } \\
\text { Beta }\end{array}$} & \multirow{2}{*}{$\mathrm{t}$} & \multirow{2}{*}{ Sig } \\
\hline & $B$ & $\begin{array}{c}\text { Std. } \\
\text { Error }\end{array}$ & & & \\
\hline (Constant) & 4,741 & 1,661 & & 2,854 & 0,006 \\
\hline kompleksitas tugas & $-0,399$ & 0,075 & $-0,498$ & $-5,330$ & 0,000 \\
\hline tekanan anggaran waktu & 0,697 & 0,140 & 0,453 & 4,962 & 0,000 \\
\hline pengalaman auditor & 0,374 & 0,069 & 0,488 & 5,430 & 0,000 \\
\hline Adjusted R Square & $: 0,589$ & & & & \\
\hline$F$ hitung & $: 27,267$ & & & & \\
\hline $\operatorname{Sig} F$ & $: 0,000$ & & & & \\
\hline
\end{tabular}

Berdasarkan Tabel 10 tersebut dapat dibuat persamaan sebagai berikut.

$$
Y=4,741-0,399 X_{1}+0,697 X_{2}+0,374 X_{3}
$$

Hasil koefisien regresi memperlihatkan nilai koefisien konstanta adalah sebesar 4,741 mempunyai arti bahwa jika variabel dianggap konstan, maka nilai variabel kualitas audit akan konstan sebesar 4,741. Nilai $\beta_{1}$ yang merupakan koefisien regresi dari variabel $\mathrm{X}_{1}$ (kompleksitas tugas) sebesar -0,399 mempunyai arti bahwa semakin tinggi kompleksitas tugas auditor atau bila terjadi peningkatan pada kompleksitas tugas auditor sebesar 1 tingkatan, maka akan terjadi penurunan kualitas audit sebesar 0,399 satuan dengan asumsi variabel lainnya tetap atatu konstan.

Nilai $\beta_{2}$ yang merupakan koefisien regresi dari variabel $\mathrm{X}_{2}$ (tekanan anggaran waktu) sebesar 0,697 mempunyai arti bahwa jika terjadi peningkatan tekanan anggaran waktu pada auditor sebesar 1 tingkatan, maka akan terjadi peningkatan kualitas audit sebesar 0,697 satuan dengan asumsi variabel lainnya 
tetap atau konstan. Nilai $\beta_{3}$ yang merupakan koefisien regresi dari variabel $\mathrm{X}_{3}$ (pengalaman auditor) sebesar 0,374 mempunyai arti bahwa jika terjadi peningkatan pengalaman auditor sebesar 1 tingkatan, maka akan terjadi peningkatan kualitas audit sebesar 0,374 satuan dengan asumsi variabel lainnya tetap konstan.

Koefisien determinasi mengukur seberapa jauh kemampuan model dalam menerangkan variabel-variabel dependen. Pada penelitian ini, koefisien determinasi yang digunakan adalah nilai dari adjusted $\mathrm{R}^{2}$. Peneliti menggunakan nilai adjusted $\mathrm{R}^{2}$ pada saat mengevaluasi yang mana model regresi terbaik, karena tidak seperti $\mathrm{R}^{2}$, nilai adjusted $\mathrm{R}^{2}$ dapat naik atau turun apabila satu variabel independen ditambahkan ke dalam model. Hasil uji memberikan hasil dimana diperoleh besarnya adjusted $\mathrm{R}^{2}$ (koefisien determinasi yang telah disesuaikan) pada Tabel 10 adalah 0,589. Ini berarti variasi kualitas audit dapat dipengaruhi secara signifikan oleh variabel kompleksitas tugas, tekanan anggaran waktu dan pengalaman auditor sebesar 58,9 persen, sedangkan sisanya sebesar 41,1 persen dijelaskan oleh faktor-faktor lain.

Hasil uji F ( F test) menunjukkan bahwa nilai $\mathrm{F}$ hitung sebesar 27,267 dengan nilai signifikansi 0,000 yang lebih kecil dari $\alpha=0,05$, ini berarti model yang digunakan pada penelitian ini adalah layak. Hasil ini memberikan makna bahwa ketiga variabel independen mampu memprediksi atau menjelaskan fenomena kualitas audit pada kantor Akuntan Publik di Bali. Hal ini berarti model dapat digunakan untuk analisa lebih lanjut atau dengan kata lain model dapat 
Ni Luh Dwi Ariestanti dan Made Yenni Latrini. Pengaruh ...

digunakan untuk mempresentasikan karena hasil goodness of fitnya baik dengan nilai F hitung sebesar 27,267 dengan nilai signifikansi 0,000.

Dari hasil perhitungan yang ditunjukan pada Tabel 10 diketahui bahwa nilai $\beta_{1}$ kompleksitas tugas sebesar - 0,399 dengan tingkat signifikansi sebesar 0,000 yang berarti dibawah nilai $\alpha=0,05$. Hal ini menunjukan bahwa variabel kompleksitas tugas berpengaruh negatif dan signifikan pada kualitas audit. Hipotesis pertama $\left(\mathrm{H}_{1}\right)$ yang menyatakan variabel kompleksitas tugas berpengaruh negative terhadap kualitas audit diterima.

Hasil penelitian ini sesuai dengan pernyataan (Restuningdiah, N. dan Indriantoro, 2000) peningkatan kompleksitas dalam suatu tugas atau sistem, akan menurunkan tingkat keberhasilan tugas itu. Terkait dengan kegiatan pengauditan, tingginya kompleksitas tugas dapat menyebabkan akuntan berperilaku disfungsional sehingga menyebabkan penurunan kualitas audit. Kompleksitas tugas didasarkan pada persepsi individu tentang kesulitan suatu tugas audit. Hasil penelitian ini juga didukung penelitian (Andin prasita dan Hadi Priyo, 2007) menunjukkan hasil bahwa, kompleksitas tugas mempunyai pengaruh negatif terhadap kualitas audit.

Berdasarkan Tabel 10 diketahui bahwa nilai $\beta_{2}$ tekanan anggaran waktu sebesar 0,697 dengan tingkat signifikansi sebesar 0,000 yang berarti dibawah nilai $\alpha=0,05$. Hal ini menunjukkan bahwa variabel tekanan anggaran waktu berpengaruh positif dan signifikan pada kualitas audit. Hipotesis kedua $\left(\mathrm{H}_{2}\right)$ yang menyatakan variabel tekanan anggaran waktu berpengaruh negatif pada kualitas 
audit dapat ditolak, karena ditemukan bahwa tekanan anggaran waktu berpengaruh positif pada kualitas audit.

Tekanan anggaran waktu adalah keadaan yang menunjukkan auditor dituntut untuk melakukan efisiensi terhadap anggaran waktu yang telah disusun atau terdapat pembatasan waktu anggaran yang sangat ketat dan kaku. Auditor seringkali bekerja dalam keterbatasan waktu, untuk itu setiap KAP perlu membuat anggaran waktu dalam kegiatan pengauditan. Pernyataan (DeZoort \& Lord, 1997) menyebutkan bahwa saat menghadapi tekanan anggaran waktu, auditor akan memberikan respon dengan dua cara yaitu, fungsional dan disfungsional. Tipe fungsional adalah perilaku auditor untuk bekerja lebih baik dan menggunakan waktu sebaik-baiknya, dimana tekanan anggaran waktu yang semakin ketat justru mendorong auditor untuk lebih semangat dalam menyelesaikan tugas auditnya sehingga dapat meningkatkan kualitas audit.

Hasil penelitian ini sesuai dengan penelitian (Sososutikno, 2003) dan(Shintya, Agneus., Muhammad Nuryatno., 2016), yang menunjukan hasil bahwa tekanan anggaran waktu berpengaruh positif terhadap kualitas audit, dimana tekanan anggaran waktu yang semakin ketat justru mendorong auditor untuk lebih semangat dalam menyelesaikan tugas auditnya sehingga dapat meningkatkan kualitas audit.

Berdasarkan Tabel 10 diketahui bahwa nilai $\beta_{3}$ pengalaman auditor sebesar 0,374 dengan tingkat signifikansi sebesar 0,000 yang berarti dibawah nilai $\alpha=0,05$. Hal ini menunjukkan bahwa variabel pengalaman auditor berpengaruh 
Ni Luh Dwi Ariestanti dan Made Yenni Latrini. Pengaruh ...

positif dan signifikan pada kualitas audit. Hipotesis kedua $\left(\mathrm{H}_{3}\right)$ yang menyatakan variabel pengalaman auditor berpengaruh positif pada kualitas audit dapat diterima.

Pengalaman kerja auditor yang melekat pada diri auditor sebagai jaminan bahwa auditor dapat meningkatkan kualitas auditnya, dengan pengalaman seorang auditor dapat menjaga sikap independensinya dalam meningkatkan kualitas audit. Pengalaman audit merupakan tingkat penguasaan dan pemahaman auditor dari lamanya auditor tersebut bekerja. Pengalaman juga terkait dengan masa kerja akuntan publik, semakin lama rentan waktu masa kerja akuntan publik juga berpengaruh terhadap setiap keputusan yang diambil (Futri \& Juliarsa, 2014).

Hasil penelitian ini didukung oleh penelitian (Agus triyanto, 2014) pengalaman auditor memberikan dampak positf terhadap kualitas auditor. (Fransiska Kovinna dan Betri, 2015) menemukan bukti bahwa pengalaman auditor akan memberikan pengaruh positif terhadap kualitas audit. Kualitas audit dapat dipengaruhi oleh pengalaman auditor seorang auditor (Basit Fauzi Nugraha, 2014). Studi empiris lain dari (Nataline, 2007) menunjukkan hasil bahwa pengalaman auditor mempunyai pengaruh positif terhadap kualitas audit. Demikian juga pada penelitian (Ananing, 2006) yang menunjukkan hasil bahwa pengalaman dan lamanya bekerja auditor berpengaruh positif terhadap peningkatan keahlian auditor dalam bidang auditing.

Berdasarkan hasil analisis maka dapat ditarik kesimpulan yaitu Kompleksitas tugas berpengaruh negatif dan signifikan pada kualitas audit. Hal ini 
berarti peningkatan kompleksitas tugas dari seorang auditor akan menurunkan kualitas audit seorang auditor. Tekanan anggaran waktu berpengaruh positif dan signifikan pada kualitas audit. Hal berarti semakin tinggi tekanan anggaran waktu yang dirasakan seorang auditor dalam menyelesaikan hasil temuan audit maka semakin baik kualitas audit seorang auditor. Pengalaman auditor berpengaruh positif dan signifikan pada kualitas audit. Hal berarti semakin banyak pengalaman yang dimiliki seorang auditor maka semakin baik kualitas audit seorang auditor.

Saran yang dapat diberikan dari hasil penelitian adalah bagi KAP hendaknya dapat menjaga dan mempertahankan kualitas audit yang dihasilkan dan dapat membantu serta mendukung auditor untuk meningkatkan kompleksitas tugas, timing tugas dan pengalaman setiap melakukan audit. Bagi auditor hendaknya mampu meningkatkan pemahaman terhadap tugas audit yang dikerjakaan untuk meminimalisir penurunan kualitas audit yang disebabkan oleh kompleksitas tugas. Dalam menetapkan waktu penugasan auditor harus mempertimbangkan dengan matang agar anggaran waktu yang ditetapkan untuk penugasan audit tidak dianggap memberatkan sehingga tidak mendorong auditor dalam melakukan tindakan disfungsional sehingga kualitas audit tidak mengalami penurunan. Dalam hal ini keahlian seorang auditor sangat dibutuhkan dalam melaksanakan audit, sehingga perlu mempunyai sertifikat jabatan fungsional auditor (JFA) dan meningkatkan keahlian dengan mengikuti pelatihan pelatihan dan pembelajaran dibidang audit secara professional dan berkelanjutan melalui seminar terhadap auditor junior agar kualitas audit yang akan dihasilkan menjadi baik. 


\section{REFERENSI}

Agus triyanto. (2014). Pengaruh skeptisisme professional auditor, situasi audit, independensi, etika, keahlian dan pengalaman terhadap ketepatan pemberian opini auditor di Kantor Akuntan Publik di wilayah Yogyakarta. Jurnal Akuntansi Muhamadiyah.

Ananing, D. A. T. (2006). Pengaruh Pengalaman Terhadap Peningkatan Keahlian Auditor Dalam Bidang Auditing. Skripsi Universitas Islam Indonesia. Yogyakarta.

Andin prasita dan Hadi Priyo. (2007). Pengaruh Tekanan Anggaran Waktu \& Kompleksitas Audit Terhadap Kualitas Audit dengan Moderasi Pemahaman Terhadap Sistem Informasi. Jurnal Ekonomi Dan Bisnis Fakultas Ekonomi Universitas Kristen Satya Wacana, (Universitas Kristen Satya Wacana).

Arens dan Loebbecke. (2003). Auditing Pendekatan Terpadu (Edisi Indo). Jakarta: Penerbit Salemba Empat.

Azad, A. N. (1994). Time Budget Pressure and Filtering of Time Practices in Internal Auditing: A Survey. Managerial Auditing Journal. https://doi.org/10.1108/02686909410061242

Basit Fauzi Nugraha, A. (2014). Pengaruh Pengalaman, Due Professional Care, dan Independensi Auditor terhadap Kualitas Audit (Survey pada Auditor Inspektorat dan BPK RI Perwakilan Provinsi Jawa Barat). Acounting.

Bonner. (1994). A Model of The Effects of Audit Task Complexity. Accounting Organization and Society, 19 (3): 213-234.

Cecilia Engko dan Gudono. (2007). Pengaruh Kompleksitas Tugas dan Locus Of Control Terhadap Hubungan Antara Gaya Kepemimpinan dan Kepuasan Kerja Auditor. JAAI, 11.

Choo, F., \& Trotman, K. T. (1991). The Relationship between Knowledge Structure and Judgments for Experienced and Inexperienced Auditors. The Accounting Review VO - 66.

Coram, P., Ng, J., \& Woodliff, D. (2003). A survey of time budget pressure and reduced audit quality among australian auditors. Australian Accounting Review. https://doi.org/10.1111/j.1835-2561.2003.tb00218.x 
DeZoort, F. T., \& Lord, A. T. (1997). A Review and Synthesis of Pressures Effects in Accounting. Journal of Accounting Literature.

Fonda. (2014). Pengaruh Tekanan Anggaran Waktu, Tipe Kepribadian Auditor, Independensi dan Kompetensi Auditor Terhadap Kualitas Audit. Skripsi. Semarang: Fakultas Ekonomika Dan Bisnis Universitas Diponegoro.

Fransiska Kovinna dan Betri. (2015). Pengaruh independensi, pengalaman kerja, kompetensi, dan etika auditor terhadap kualitas audit pada KAP di kota Palembang. Akuntansi.

Futri, P. S., \& Juliarsa, G. (2014). Pengaruh Independensi, Profesionalisme,Tingkat Pendidikan, Etika Profesi, Pengalaman, Dan Kepuasan Kerja Auditor Pada Kualitas Audit Kantor Akuntan Publik Di Bali. E-Jurnal Akuntansi Universitas Udayana. https://doi.org/10.1111/j.1365-2761.1986.tb01041.x

Ghozali, I. (2015). Aplikasi Analisis Multivariatre dengan Program IMB SPSS.

Hardiningsih, P. D. S. (2002). Pengaruh Pengalaman Terhadap Profesionalisme Serta Pengaruh Terhadap Kinerja Dan Kepuasan Kerja. Jurnal Bisnis Dan Ekonomi, 9.

Hidayat, M. (2011). Pengaruh Faktor-Faktor Akuntabilitas Auditor Dan Profesionalisme Auditor Terhadap Kualitas Auditor (Studi Empiris Pada Kantor Akuntan Publik Di Semarang). Universitas Diponegoro. Semarang.

Jamilah , Siti, Fanani , Zaenal dan Chandrarin, G. (2007). engaruh Gender, Tekanan Ketaatan dan Kompleksitas Tugas Terhadap Audit Judgment. Simposium Nasional Akuntansi X.

Jauhari, D. D. (2013). Pengaruh Independensi, Pengalaman Dan Akuntabilitas Terhadap Kualitas Audit. Jurnal Publikasi. Jurnal Publikasi.

Josoprijonggo, M. D. (2005). Pengaruh Batasan Waktu Audit Terhadap Kualitas Audit dan Kepuasan Kerja Auditor. Disertasi. Salatiga: Fakultas Ekonomi Satya Wacana.

Kane, G. D., \& Velury, U. (2005). The Impact of Managerial Ownership on the Likelihood of Provision of High Quality Auditing Services. Review of Accounting and Finance. https://doi.org/10.1108/eb043424

Loehoer, R. dan J. H. J. (2002). Manajemen Sumber Daya Manusia. Jakarta: Prenhallindo: Salemba Empat. 
Nataline. (2007). Pengaruh Batasan Waktu Audit, Pengetahuan Akuntansi Dan Auditing, Bonus Serta Pengalaman Terhadap Kualitas Audit Pada Kantor Akuntan Publik Di Semarang. Skripsi. Semarang: Fakultas Ekonomika Dan Bisnis Universitas Diponegorosi. UNNES.

Okezone.com. (2011). Audit BPKP, Korupsi di Bali Capai Rp17 Miliar. Retrieved from https://economy.okezone.com/read/2011/05/31/20/462818/audit-bpkpkorupsi-di-bali-capai-rp17-miliar

R. Libby. (1995). The Role of knowledge and Memory in audit Judgement. In Judgement and Decision-Making. Reserarch in Accounting and Auditing edited by R. Ashton, and A. Ashton. Cambridge University Press.

Restuningdiah, N. dan Indriantoro, N. (2000). Pengaruh Partisipasi Terhadap Kepuasan Pemakai Dalam Pengembangan Sistem Informasi Dengan Kompleksitas Tugas, Kompleksitas Sistem, Dan Pengaruh Pemakai Sebagai Moderating Variabel. Jurnal Riset Akuntansi Indonesia.

Setyawati, Y. (2010). Pengaruh Kompleksitas Audit, Pengalaman Auditor Dan Independensi Auditor Terhadap Kualitas Audit (Studi Empiris Pada Kantor Akuntan Publik Di Jawa Tengah Dan Yogyakarta). Jurnal Ilmiah.

Shintya, Agneus., Muhammad Nuryatno., dan A. A. O. (2016). Pengaruh Kompetensi, Independensi, Dan Tekanan Anggaran Waktu Terhadap Kualitas Audit. Seminar Nasional Cendekiawan.

Simanjuntak, P. (2008). Pengaruh Time Budget Pressure dan Resiko Kesalahan Terhadap Penurunan Kualitas Audit (Studi Empiris pada Auditor KAP di Jakarta). Diponegoro Journal of Accounting.

Solomon, I. Shields, dan M. (1995). Judgment and Decision Making Research in Auditing. In judgment and Decision - Making. Research in Accounting and Auditing, Edited by R. Ashton and A. Ashton. NY: Cambridge University Press. New York.

Sososutikno, C. (2003). Hubungan Tekanan Anggaran Waktu dengan Perilaku Disfungsional serta Pengaruhnya terhadap Kualitas Audit. Simposium Nasional Akuntansi VI Surabaya.

Sugiyono. (2017). Metode Penelitian Kuantitatif, Kualitatif dan $R \& B$. Bandung: Alfabeta.

T. Jurnali. (2001). Analisis Pengaruh Faktor Kesesuaian Tugas-Teknologi dan Pemanfaatan Teknologi Informasi terhadap Kinerja Akuntansi Publik. 


\section{Simposium Nasional Akuntansi IV}

Tan, H.-T., \& Kao, A. (1999). Accountability Effects on Auditors' Performance: Influence of Knowledge, Problem-Solving Ability, and Task Complexity. SSRN. https://doi.org/10.2139/ssrn.147869

Agus triyanto. (2014). Pengaruh skeptisisme professional auditor, situasi audit, independensi, etika, keahlian dan pengalaman terhadap ketepatan pemberian opini auditor di Kantor Akuntan Publik di wilayah Yogyakarta. Jurnal Akuntansi Muhamadiyah.

Ananing, D. A. T. (2006). Pengaruh Pengalaman Terhadap Peningkatan Keahlian Auditor Dalam Bidang Auditing. Skripsi Universitas Islam Indonesia. Yogyakarta.

Andin prasita dan Hadi Priyo. (2007). Pengaruh Tekanan Anggaran Waktu \& Kompleksitas Audit Terhadap Kualitas Audit dengan Moderasi Pemahaman Terhadap Sistem Informasi. Jurnal Ekonomi dan Bisnis Fakultas Ekonomi Universitas Kristen Satya Wacana, (Universitas Kristen Satya Wacana).

Arens dan Loebbecke. (2003). Auditing Pendekatan Terpadu (Edisi Indo). Jakarta: Penerbit Salemba Empat.

Azad, A. N. (1994). Time Budget Pressure and Filtering of Time Practices in Internal Auditing: A Survey. Managerial Auditing Journal. https://doi.org/10.1108/02686909410061242

Basit Fauzi Nugraha, A. (2014). Pengaruh Pengalaman, Due Professional Care, dan Independensi Auditor terhadap Kualitas Audit (Survey pada Auditor Inspektorat dan BPK RI Perwakilan Provinsi Jawa Barat). Acounting.

Bonner. (1994). A Model of The Effects of Audit Task Complexity. Accounting Organization and Society, 19 (3): 213-234.

Cecilia Engko dan Gudono. (2007). Pengaruh Kompleksitas Tugas dan Locus Of Control Terhadap Hubungan Antara Gaya Kepemimpinan dan Kepuasan Kerja Auditor. JAAI, 11.

Choo, F., \& Trotman, K. T. (1991). The Relationship between Knowledge Structure and Judgments for Experienced and Inexperienced Auditors. The Accounting Review VO - 66.

Coram, P., Ng, J., \& Woodliff, D. (2003). A survey of time budget pressure and reduced audit quality among australian auditors. Australian Accounting Review. https://doi.org/10.1111/j.1835-2561.2003.tb00218.x 
DeZoort, F. T., \& Lord, A. T. (1997). A Review and Synthesis of Pressures Effects in Accounting. Journal of Accounting Literature.

Fonda. (2014). Pengaruh Tekanan Anggaran Waktu, Tipe Kepribadian Auditor, Independensi dan Kompetensi Auditor Terhadap Kualitas Audit. Skripsi. Semarang: Fakultas Ekonomika dan Bisnis Universitas Diponegoro.

Fransiska Kovinna dan Betri. (2015). Pengaruh independensi, pengalaman kerja, kompetensi, dan etika auditor terhadap kualitas audit pada KAP di kota Palembang. Akuntansi.

Futri, P. S., \& Juliarsa, G. (2014). Pengaruh Independensi, Profesionalisme,Tingkat Pendidikan, Etika Profesi, Pengalaman, Dan Kepuasan Kerja Auditor Pada Kualitas Audit Kantor Akuntan Publik Di Bali. E-Jurnal Akuntansi Universitas Udayana. https://doi.org/10.1111/j.1365-2761.1986.tb01041.x

Ghozali, I. (2015). Aplikasi Analisis Multivariatre dengan Program IMB SPSS.

Hardiningsih, P. D. S. (2002). Pengaruh Pengalaman Terhadap Profesionalisme Serta Pengaruh Terhadap Kinerja Dan Kepuasan Kerja. Jurnal Bisnis Dan Ekonomi, 9.

Hidayat, M. (2011). Pengaruh Faktor-Faktor Akuntabilitas Auditor Dan Profesionalisme Auditor Terhadap Kualitas Auditor (Studi Empiris Pada Kantor Akuntan Publik Di Semarang). Universitas Diponegoro. Semarang.

Jamilah , Siti, Fanani , Zaenal dan Chandrarin, G. (2007). engaruh Gender, Tekanan Ketaatan dan Kompleksitas Tugas Terhadap Audit Judgment. Simposium Nasional Akuntansi X.

Jauhari, D. D. (2013). Pengaruh Independensi, Pengalaman Dan Akuntabilitas Terhadap Kualitas Audit. Jurnal Publikasi. Jurnal Publikasi.

Josoprijonggo, M. D. (2005). Pengaruh Batasan Waktu Audit Terhadap Kualitas Audit dan Kepuasan Kerja Auditor. Disertasi. Salatiga: Fakultas Ekonomi Satya Wacana.

Kane, G. D., \& Velury, U. (2005). The Impact of Managerial Ownership on the Likelihood of Provision of High Quality Auditing Services. Review of Accounting and Finance. https://doi.org/10.1108/eb043424 
Loehoer, R. dan J. H. J. (2002). Manajemen Sumber Daya Manusia. Jakarta: Prenhallindo: Salemba Empat.

Nataline. (2007). Pengaruh Batasan Waktu Audit, Pengetahuan Akuntansi Dan Auditing, Bonus Serta Pengalaman Terhadap Kualitas Audit Pada Kantor Akuntan Publik Di Semarang. Skripsi. Semarang: Fakultas Ekonomika dan Bisnis Universitas Diponegorosi. UNNES.

Okezone.com. (2011). Audit BPKP, Korupsi di Bali Capai Rp17 Miliar.

R. Libby. (1995). The Role of knowledge and Memory in audit Judgement. In Judgement and Decision-Making. Reserarch in Accounting and Auditing edited by R. Ashton, and A. Ashton. Cambridge university press.

Restuningdiah, N. \& Indriantoro, N. (2000). Pengaruh Partisipasi Terhadap Kepuasan Pemakai Dalam Pengembangan Sistem Informasi Dengan Kompleksitas Tugas, Kompleksitas Sistem, Dan Pengaruh Pemakai Sebagai Moderating Variabel. Jurnal Riset Akuntansi Indonesia.

Setyawati, Y. (2010). Pengaruh Kompleksitas Audit, Pengalaman Auditor Dan Independensi Auditor Terhadap Kualitas Audit (Studi Empiris Pada Kantor Akuntan Publik Di Jawa Tengah Dan Yogyakarta). Jurnal Ilmiah.

Shintya, Agneus., Muhammad Nuryatno., dan A. A. O. (2016). Pengaruh Kompetensi, Independensi, Dan Tekanan Anggaran Waktu Terhadap Kualitas Audit. Seminar Nasional Cendekiawan.

Simanjuntak, P. (2008). Pengaruh Time Budget Pressure dan Resiko Kesalahan Terhadap Penurunan Kualitas Audit (Studi Empiris pada Auditor KAP di Jakarta). Diponegoro Journal of Accounting.

Solomon, I. Shields, dan M. (1995). Judgment and Decision Making Research in Auditing. In judgment and Decision - Making. Research in Accounting and Auditing, edited by $R$. Ashton and A. Ashton. NY: Cambridge University Press. New York.

Sososutikno, C. (2003). Hubungan Tekanan Anggaran Waktu dengan Perilaku Disfungsional serta Pengaruhnya terhadap Kualitas Audit. Simposium Nasional Akuntansi VI Surabaya.

Sugiyono. (2017). Metode Penelitian Kuantitatif, Kualitatif dan $R \&$ B. Bandung: Alfabeta. 
Ni Luh Dwi Ariestanti dan Made Yenni Latrini. Pengaruh ...

T. Jurnali. (2001). Analisis Pengaruh Faktor Kesesuaian Tugas-Teknologi dan Pemanfaatan Teknologi Informasi terhadap Kinerja Akuntansi Publik. Simposium Nasional Akuntansi IV.

Tan, H.-T., \& Kao, A. (1999). Accountability Effects on Auditors' Performance: Influence of Knowledge, Problem-Solving Ability, and Task Complexity. SSRN. https://doi.org/10.2139/ssrn.147869 